\title{
THEORETICAL ASPECTS OF STUDYING THE GENRE OF HISTORICAL NOVELS IN MODERN LITERARY CRITICISM
}

\author{
Dautova S.B., Ospanova B.R. \\ RSE PVC "Kazakh State University Abay", Almaty, e-mail: baian_80@mail.ru \\ Interest in historical romanticism has always been present in all literature, although this emphasis is par- \\ ticularly important in the comparative context of literary criticism genres. The historical novel, which was formed \\ during romanticism in western European literature, showed its artistic features in the national literature of the later \\ period with a clear and original expression. The comparative and typological consideration of the genre originality \\ of these works is of great importance in the context of general cultural ties and the general evolution of the genre of \\ history. The article is aimed at researching the artistic concepts of the historical personality in the literary process in \\ the milestones in a changing socio-cultural context. On the basis of the latest research strategies, a systematic study \\ of the artistic concept of the historical personality of the great figures of the era of the Golden Horde, who are of key \\ importance in the formation of the statehood of Kazakhstan, will be carried out. A fundamentally new formulation \\ of the problem involves the study of the evolution of the artistic concept of national history on the basis of historical \\ novels of the XX and XXI centuries in the milestones - Soviet, post-Soviet, the period of independence of modern \\ Kazakhstan.
}

Keywords: that characterize the industry and the application direction for the experts selection: Philology, literary studies, artistic concept, historical personality, historical novel, the Golden Horde era

Since its emergence in the system of literary genres, the genre image of a historical novel has long been a platform for theoretical discussion at a certain level. This is determined by the genre search, both within the boundaries of the structure of the novel's forms and within the architext of the novel, since the novel became the dominant genre among other artistic forms in the twentieth century. If we analyze the formation and change of the historical genre in the context of the changes observed in World Literature, in the sphere of culture in general, without elaborating or concretizing, it should be noted that the historical novel absorbs all these changes, giving it a different look, creating its genre achievements. That is why we consider a comprehensive description of the genre of a historical novel to be the most productive way to study its structural type. In the theory of literature, there are several approaches to the study of genre categories. Summing up, we can say that they are thematic, functional and structural. It is known that there are several facets of genre classification, each of which describes a different area and function of a complex structural type of aesthetic work. When studying the genre nature of a historical novel as a genre formation in a very large social sphere, we must determine what is the static core of the novel type under study and what caused it to undergo dynamic changes. In Literary Studies, a genre is a kind of solid structure characterized by a dichotomic structure with repetitive features, i.e.: "a genre is a stable structure in which some of the content of an event is formed, as well as dialectical harmony, in which different types of lexical and compositional systems and their content beginnings interact".
In some literary works, it is also suggested that 1 genre-forming dominant feature includes a problematic beginning, which becomes a certain type of plot-compositional structure. Other researchers give priority to the role of the structural and compositional form: "the genre, like all art forms, is a form that has been strengthened, transformed into a certain literary structure of content".

In the science of literature, there are other aspects of commenting on a genre. In them, this category of literary studies is considered from different theoretical points of view: on the one hand, the genre is relatively stable, according to which its typological feature is indicated; on the other hand, its mobility, variability is observed, and this aspect is studied by coming from a specific historical point of view. The study of the genre from a typical point of view is considered in the works of V. Kozhinov, G. Pospelov. The study of the latter is connected with time, so it is constantly in motion.

At the turn of the XX-XXI centuries, the novel is undergoing a significant genre change, becoming an experimental (experimental) platform of various artistic approaches, and traditional and non-traditional, ancient and innovative aesthetic forms are mixed. Analyzing the current literary process, researchers believe that the idea that the novel is over may be a sign of something else, that is, the novel's integrity reflects the process of becoming a "meeting place" and a dialogue of different cultural traditions and views. For example, N.T. Rymar concludes that "despite the differences in the content and plot-compositional form of the novel of the twentieth century from the traditional form, the structure of the novel thinking does not disappear, only the form of its presentation 
in the poetics of the novel changes significantly." The search for new genre forms is also reflected in the structural state of the historical novel.

Hegel's conclusion about the genre content of the novel belongs to him. He was the first to pay attention to its socio-historical origin, thus emphasizing that the aesthetic phenomenon of the genre will be meaningful because it will contain the concept of man and reality. The philosopher considers the origin of the novel genre in connection with a certain social situation in which the conflict between the individual and society becomes clearer and clearer. At the beginning of the formation of the individual, the complication of the individual's self-expression determines the nature of the conflict in the novel.

First of all, the lack of research of the Golden Horde epoch. This was due to an official ban on the Golden Horde in 1944, which was extended to the 1980s. T. Kozyrev notes: "then everything was done to erase the Golden Horde from the memory of the people. ... the historical consciousness of the Kazakhs and other Turkic peoples of the USSR during the Stalinist period underwent a vivisection of unprecedented scale" [1].

Secondly, an important precondition for domestic science, including philological, is the significance of the Golden Age as an object of science. The departure from history, the subsequent study of science and the formation of the formative period of the Kazakh state had a serious consequence and gave rise to "mancurtism" - the historical disgrace of generations of people. Scientists note that the period of the Great Ulus remains a white spot, not enough specialists, scientific centers, complex research. R. Temïrgaliev Communication, read govorya Kazakh goswdarstvennostï Golden Horde conviction: "naxojdenïe invention vnïmanïya stol dlitelnogo istorïçeskogo otrezka lisşaet celnosti our story ... So poyavlyaetsya neopravdanniy draws vremennoy razriv, propadaet logic of history, thousands wtraçivaem ponïmanïe prïçïnno sledstvennix svyazey ïstorïçeskïx processax" [2].

In the third and third centuries, the necessity of returning the Golden Horde heritage to scientific, educational, social and historical space became known. In 2019, the President of the Republic of Kazakhstan K. Tokayev in his Message to the people of Kazakhstan emphasized the role of the Golden Horde in the statehood of the republic. The year of the 750th anniversary of the Golden Horde was announced in Kazakhstan in 2020. An indisputable fact: the heart of the Kazakh land - Ulytau is historically associated with the names of great personalities of the Golden Horde of Juchi Khan and Batu Khan. Here was the bet of Juchi Khan - the founder of the Great Nation - the Great State. Here in the sacred place of the Kazakh Steppe will rest its rest.

K.Zh. Tokayev spoke about the necessity to give this historical justice: "We must pay tribute to the founder of the Golden Horde Dzhukikhan. Very important mission: to pay attention to the whole world on such a historical figure ..." [3].

Literature plays an important role in changing the historical discourse in understanding the history of the Golden Horde. Historical genres of fiction contribute to the formation of paintings of the human world, create artistic models of significant periods of history. The history of the Golden Odyssey and its great figures are the subject of a multitude of works of art of various genres. Among the new works you can name the following historical novels: Kalashnikov I. "Cruel Century" (2018), Zatsarinny S. "Empty cell" (2015), Pochekaev R. "Baty. Khan, who was not a khan "(2007), Leo de Hortog" Genghis Khan. Conqueror of the World "(2017) and others.

Ignoring the significance of the epoch in the public consciousness, there is a contradiction associated with the lack of research on the subject. Contradictions are observed and in the perception of historical personalities of the Golden Horde - Juchi-khan, Baty-khan and others. Cognitive knowledge and great historical figures of Kazakhstanis know little about their role in domestic history.

The concept of historical personality is key in the artistic interpretation of boundary periods of history. The artistic re-creation of their peasantry restores the historical consciousness of society. In the era of total entanglement of complex themes of fiction, individual writers had the courage to remember the lessons of history, to awaken in man the historical memory. One of such personalities was I. Esenberlin. Scholars agree that the Golden Horde trilogy was the only work of Soviet Kazakh literature on the glorious period of domestic history. Out of 17 novels by the writer, 6 are dedicated to the Kazakh Khanate and the Golden Horde.

The subject of research are the concepts of great historical personalities of the Golden Horde period on the basis of fiction. The object of research are historical novels of the XX and XXI centuries on the theme of the Golden Horde, characterized by diversity and created 
in different historical times in different sociopolitical and socio-cultural context.

The study material selected the most representative, reflecting the shift of socio-cultural paradigms, historical novels: the trilogy of Vasily Yana "Invasion of the Mongols", consisting of novels "Chingizkhan" (1939), "195em" (195) [4]; Ilyas Esenberlina's trilogy "Golden Horde" - 1 book "Six-headed Dragon" (1982), 2 books "Head of the Dragon" (1985), 3 books "Destruction of the Dragon" [5]; dilogy Mukhtara Magauina "Shyngys khan" (2011) 1 book "Uyiskan ulus", 2 books "Shyngys khan" [6]; dilogy by Nurlan Sanjar "Warrior of the Golden Horde", consisting of novels "The Unexpected Guest - Juchi” (2019), "Batukhan" (2020) [7]. Modern scientists note the free-flowing, unique concreteness of the novel form, which is directed to new artistic possibilities, "the novel takes the direction of life itself with objective socio-realistic laws" and at the same time reflects in it: "the author's power of the subject". "The subjectivization of the novel is carried out through the deepening of its objective-subjective essence".

In the context of recent decades, when cultural paradigms are changing, and the author's stability of understanding the picture of the world is broken down into small details in many individual views, such aesthetic States, of course, lead to an artistic transformation of the novel's form. The flexibility of the aesthetic form of the novel necessarily prompted researchers to determine the dialectical relationship between stability and variability in the genre. This distinction is especially important for a historical novel that appears on the border of two humanitarian systems - literature and history.

The genre of historical novels was first reflected in the works of Walter Scott in the era of romanticism. The emergence of this genre in the cultural life of society mainly increases interest in history itself, a sense of the need for radical social changes, the need to understand their causes and consequences. In this transitional period, when historiography began to understand itself as an autonomous scientific field, Scott wrote his books, developing his methodology and determining from what point of view it is necessary to approach research.

According to researchers, his historical novels absorbed the literary tradition of aesthetic representation of reality, such as the epics of his predecessors, enlightenment, gothic novels, educational novels and historical dramas of novelists. Literary critics attribute to him the fact that he added artistic fabric to works of local colour. The creative novelty his- torical novel is considered to be the law of the historical future, in which "it was necessary to show where events lead, to show the future that appears in the ruins of the disasters of the past".

The creative significance of the novelty of the historical novel, its role in the literary process is comprehensively analysed in the works of major foreign and domestic theorists. Researchers note that the origin of the Russian historical novel is due to a certain socioeconomic and cultural situation in comparison with Western versions, and note that they have a lot in common with Scott's novel. When analysing the aesthetic features of Russian historical works of that time, literary critics note that their poetic structure contains the structure of artistic formulas discovered by the Scottish writer and other authors.

Researchers note that the works of this period are characterized by the fact that the authors describe the events of the past time of the country, the complex destinies of Russian culture and its visible representatives, in which the pages of the novel reflect repeated events in the formation of Russian statehood. According to S. Petrov, the works of these periods are characterized by "genre diversity, in which" the methods of revealing the character of the hero are improved", "the spectrum of individual styles is beginning to expand".

The constant improvement of the existential quality of a person, the desire to find his place in the world, his deep-rooted interest, the desire for solitude, all gives an impetus to the further development of the genre of historical novels. The diversity of artistic representation creates difficulties in determining the boundaries of the genre. In many works, the specifics of the genre are studied from the point of view of thematic and ideological content, but in the collective monograph "historical novel in the literature of the socialist countries of Europe", the originality of the genre is considered from the point of view of the poetic structure of the work. We consider this definition of the genre specificity of a historical novel to be quite correct.

Since the genre of the historical novel primarily speaks about the past, that is, describes the event that occurred, it allows us to consider the structuring of the genre as a semiotic system, moreover, like any genre types, it has both content and form aspects. When considering a work of art as a "multi-layered sign system" divides it into two levels into a layer of an artistic system consisting of its own linguistic, grammatical and world modelling, virtual-subject and mythological features. 
Based on the analysis of the theoretical problem of the genre from different points of view, it is advisable to consider the genre features of a group of works grouped according to certain characteristics or formed into a separate aesthetic whole in the aspect of semiotics.

A genre or, to a large extent, a genre system, like any feature, has conditional and substantive aspects that accumulate multiplicity and multiplicity, respectively, at different levels of manifestation in a genre semiotic system.

Summarizing the above-mentioned theoretical research and based on the semiotic nature of the genre, The Miracle of historical novels is that the past life does not lose its mystery here. The historical novelist does not allow the romance language to become too archaism, preserving the originality of the patterns of words, clothing, traditions to convey the colour of the past era, and at the same time making it understandable to the modern reader. In historical novels, the peculiarity of writing a novel is preserved by accurately presenting historical events, the task of the historian is fulfilled, and the thoughts and feelings of the people who took place in it are transmitted as they are. The relationship between history and literature in the genre of a historical novel is that it is realized in the tradition of mutual continuity and continuity. That is, the author of a historical novel, working with specific documents, historical data, must comply with the goal of not distorting historical reality and the technique of the novel, the requirements for its artistry. On the problems of reality and realism in a work of art, the scientist And the following scientist, a researcher of historical novels B.K. Bazylova: "historical novels reflect a certain historical concept of social and social development. In his historical novels, the writer tries to portray the past with sincerity, the meaningfulness of which is judged by the measure of his knowledge of history and talent", he quotes $[8,4]$. This view is typical for the work of historical novelists in Kazakh literature because Kazakh historical novelism is not characterized by romantic writing, it is often guided by the reality principle. I. Yessenberlin's historical trilogies "Nomads" and "Golden Horde", which enriched the genre of historical novels in Kazakh literature and made a great contribution to the development of the genre. In the trilogy" Nomads", the writer, using sufficient historical data, accurately reflected the stages of formation and development of the Kazakh state in the period from the XI to the XIX centuries and adapted the literary and artistic personalities of outstanding citizens of the Kazakh people to a convincing and historical reality. The value of the writer's historical novels is the ability of I. Yessenberlin to contain significant events of five centuries of history in his works, his ability to highlight important, key manifestations of history. One of the founders of the historical novel of Ilyas Yesenberlin in modern Kazakh literature. Among the first writers to open little-studied pages of national history, turning their eyes to the Ancient Origins of the Kazakh people in their research. The author's trilogies "Nomads" and "Altyn Orda" are an outstanding study of Kazakh historical prose in terms of their expressive colouring and artistic expression of the historical era. When the Nomad trilogy was released, critics had different opinions about it. The views of writer I. Yesenberlin on the past and its connection with historical science are often found in the works of Russian literary scientists. What situation should rise above this in a historical novel: historical reality or the artistic imagination of the writer? - the question arises. Some support the importance of document-based content, while others support the priority of artistic content. Analyzing such questions, researchers show the predominance of the opinion that the main criterion of a historical novel is a historical truth. Since the time relief in the trilogy covers five hundred years, the events here can be considered as the period of the Genghis Khan dynasty. In the trilogy of the writer, the sequence of plots is not preserved, because the works of Ilyas Yesenberlin contain a lot of historical data and archival documents, as well as real facts. Therefore, the author not only assimilated these data but also presented the artistic reality of the described era. This study is of great importance in studying the peculiarities of the inner world of time and space - art, including literatureimportant worldview, ideological-content and artistic work, solving complex problems of the content and form of the work.

The scientist M.M. Bakhtin, who laid the foundations of the concept of "chronotope" in Literary Studies, said: "Chronotope is a formal and substantive category of literature... In the literary and artistic chronotope, the signs of space and time are intertwined as a meaningful and real whole". In his opinion, in most cases, the relation of time was considered separately from space. The image of time is formed from biographical (childhood, youth, maturity, old age), historical (exchange of epochs and generations in the life of society, major events), cosmic (thoughts on eternal and world history), calendar (alternation of seasons, everyday life and holidays), diurnal 
(day and night, morning and evening time), as well as thoughts about movement and immobility, the relationship of the Past, Present, Future. And space is reflected in works of art in different ways: closed and open space, Earth and cosmic space, real and imaginary space visible to the naked eye, the idea of the substance of near and far. Works of art can bring different spaces closer together and flow into one channel. He shows the relationship between time and spatial views, calling the chronotope "time-space", and connects the chronotope with the novel type of creativity.

In conclusion, it shows that time and space in Kazakh novels have expanded and become more complex. it is distinguished by the dynamism of events, the image of vivid and unique personalities of Kazakh history, the sincerity and clarity of the language." Ilyas Yessenberlin is a master of historical novels, and historical works born from his pen are distinguished by the fact that they contain all the qualities inherent in historical novels in terms of artistic power.

\section{References}

1. Kozyrev T. The Golden Horde - the golden cradle: the origins of Kazakh statehood and modernity. Liter. 09/04/2019. $3 \mathrm{p}$.

2. Temirgaliev R. There can be no question of the privatization of the historical heritage of the Golden Horde by Kazakhstan. Caravan. 20.02.2020. 1p.

3. Tokaev K-Zh. Kazakhstan will celebrate the 750th anniversary of the Golden Horde. TVNZ. August 27, 2019. P. 247.

4. Vasily Yan: Invasion of the Mongols. M.: AST, 2015. $1056 \mathrm{p}$.

5. Esenberlin I. The Golden Horde. St. Petersburg: Leningrad Publishing House. 2016. 560 p.

6. Magauin M. Shygys khan. T. 1, T. 2. Almaty: Dauir, $2016.675 \mathrm{p}$.

7. Sanzhar N. Warriors of the Golden Horde. Almaty: Meloman Publishing, 2019. $496 \mathrm{p}$.

8. Bazylova B.K., Kalinina V.V. The author's concept of the character in the historical novel. International Journal of Applied and Fundamental Research. 2016. No. 5. P. 808-812. 